\title{
Virus Punta Toro: un Phlebovirus circulante en América
}

\author{
Punta Toro virus: a Phlebovirus circulating in America \\ Iván Renato Zúñiga Carrasco,* Janett Caro Lozano ${ }^{\ddagger}$ \\ * Jefe del Departamento de Epidemiología. UMF No. 223, IMSS, Lerma, México. \\ ‡ Jefa del Departamento de Epidemiología. HGZ, C/M.F. No. 1, IMSS, Chetumal, Quintana Roo.
}

RESUMEN

\begin{abstract}
Virus Punta Toro (género Phlebovirus, familia Bunyaviridae), miembro del grupo de la fiebre de la mosca de la arena, se describió inicialmente en humanos en 1966 después de haber sido aislado de un soldado en Panamá que tenía fiebre, dolor de cabeza, mialgia y leucopenia. El VPT, un bunyavirus transmitido por mosquitos, generalmente causa una infección leve y autolimitada en los humanos, pero puede progresar a una enfermedad febril aguda. Tanto en infecciones humanas como en animales los determinantes genéticos del hospedador probablemente contribuyen a la patogénesis del flebovirus.
\end{abstract}

Palabras clave: Virus Punta Toro, Phlebovirus, Bunyaviridae, alfavirus.

\section{INTRODUCCIÓN}

En 2009 se reportó un brote de dengue en la ciudad de Panamá. El Institute Gorgas Memorial de dicha ciudad analizó muestras negativas a dengue, de este brote se procesaron muestras para detectar alfavirus, flavivirus y flebovirus, y cuál fue la sorpresa al detectar el complejo de especies del Virus Punta Toro (VPT) en algunos ejemplares.

En dicha investigación de 2009 se analizaron 4,852 muestras de personas en Panamá con sospecha de dengue; 1,667 (34.4\%) de las muestras fueron dengue negativo. Además, se analizaron 201 de estas muestras para detectar flebovirus, se extrajo el ARN viral de las muestras, se evaluaron utilizando la PCR de transcripción inversa (RT-PCR)

Abreviaturas:

VPT $=$ Virus Punta Toro

PTV $=$ Punta Toro Virus

Financiamiento: Ninguno.

Conflicto de intereses: Ninguno.

https://dx.doi.org/10.35366/95647

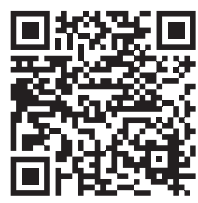

ABSTRACT

Punta Toro Virus (genus Phlebovirus, family Bunyaviridae), a member of the sandfly fever group, was initially described in humans in 1966 after being isolated from a soldier in Panama who had a fever, headache, myalgia and leukopenia PTV, a mosquito-borne bunyavirus, usually causes a mild and self-limited infection in humans, but can progress to acute febrile illness. In both human and animal infections, the genetic determinants of the host probably contribute to the pathogenesis of flebovirus

Keywords: Punta toro virus, Phlebovirus, Bunyaviridae, alfavirus.

específica para el género Phlebovirus basada en Gen $L$ (grande) que detecta los virus de la fiebre de: Toscana, Nápoles, Sicilia, Aguacate, Punta Toro y Valle del Rift. Se analizaron ejemplares utilizando pan-flavivirus y pan-alphavirus RT-PCR. De las 201 muestras, 27 (13.4\%) fueron RT-PCR positivas para Phlebovirus. Los pacientes de caso positivos a VPT se encontraban en gran parte en el área metropolitana de la ciudad de Panamá. Los pacientes y los controles de casos se compararon principalmente con respecto a los síntomas informados.

EI VPT (género Phlebovirus, familia Bunyaviridae), miembro del grupo de la fiebre de la mosca de la arena, se describió inicialmente en humanos en 1966 después de haber sido aislado de un soldado en Panamá que tenía fiebre, dolor de cabeza, mialgia y leucopenia.

\section{CARACTERÍSTICAS}

La familia Bunyaviridae está actualmente dividida en cinco géneros: Orthobunyavirus, Nairovirus, Hantavirus, Phlebovirus y Tospovirus que comprende más 
de 350 especies de virus diferentes. Patógenos humanos se encuentran en cada uno de los géneros, a excepción de los Tospovirus, que sólo infectan las plantas. Genomas de Bunyaviridae incluye tres moléculas únicas negativas o ambisense (es una situación en la que tanto el genoma como su complemento contienen información de codificación). ARN SS (virus ARN monocatenario negativo), designado $\mathrm{L}$ (grande), M (medio) y S (pequeño) con una longitud combinada de 11-19 kb. Como en otros virus segmentados de familias, la reagrupación genética es frecuente y ha sido demostrado entre bunyavirus relacionados tanto in vitro e in vivo.

El género Phlebovirus comprende aproximadamente 70 virus que se clasifican (según su capacidad antigénica, genómica y/o relaciones vectoriales), en dos grandes grupos: el grupo de la fiebre de la mosca de la arena, que incluye la fiebre del Valle del Rift y los virus de Toscana (se transmite por mosquitos y moscas de la arena de la especie flebotomina), y el grupo Uukuniemi, que son transmitidos por garrapatas e incluyen tres nuevos virus emergentes de importancia para la salud pública, fiebre grave con síndrome de trombocitopenia, virus Heartland y Bhanja. Recientemente, se describió un tercer linaje (grupo) distinto dentro del género Phlebovirus y está compuesto por dos virus específicos para mosquitos, el virus Gouleako y el virus Cumuto.

Debido a la importancia para la salud pública de algunos virus en el género Phlebovirus, y en un esfuerzo por desarrollar un sistema taxonómico más preciso para la clasificación de los Phlebovirus, se han intentado secuenciar todos los virus nombrados disponibles en el género para determinar sus relaciones filogenéticas. La cepa Balliet de VPT se aisló en 1966 de la sangre de un soldado febril involucrado, quien estaba entrenando en la selva de la provincia de Colón, en la antigua Zona del Canal de Panamá. Un segundo aislamiento de VPT, la cepa Adames, se aisló en 1972 de la sangre de un entomólogo que desarrolló una enfermedad febril durante un viaje de recolección a una zona boscosa de la provincia de Darién. ${ }^{2}$

\section{EPIDEMIOLOGÍA}

Los casos de infección por VPT en el brote de Panamá se produjeron en áreas urbanas y periurbanas. ${ }^{1}$

EI VPT, un bunyavirus transmitido por mosquitos, generalmente causa una infección leve y autolimitada en los humanos, pero puede progresar a una enfermedad febril aguda. ${ }^{3}$

\section{CUADRO CLÍNICO}

Fiebre, escalofríos, cefalea intensa, dolor retroorbitario, tos, dolor de garganta, coriza, náusea, vómito, diarrea, petequias, exantema, mialgia, artralgia, debilidad, dolor de espalda, hepatomegalia y esplenomegalia.

\section{LABORATORIO}

Para evaluar el daño hepático se cuantifican las concentraciones séricas de alanina aminotransferasa (ALT). Al tercer día los pacientes llegan a tener un pico pronunciado en ALT, alcanzando una concentración media de 7,000 Ul/mL. Los niveles van disminuyendo sustancialmente en el cuarto día (3,400 UI/ $\mathrm{mL}$ ) y regresa a los niveles de referencia normales al quinto día. Se puede presentar leucopenia. Tanto en infecciones humanas como en animales los determinantes genéticos del hospedador probablemente contribuyen a la patogénesis del flebovirus.

EI VPT es detectable en suero y tejidos entre los días uno a tres. ${ }^{4}$

\section{PATOLOGíA}

Desde el punto de vista histológico, el hígado infectado con VPT parece normal hasta el día tres de la infección, momento en el cual las áreas coalescentes de necrosis hepatocelular aguda severa son evidentes; en el día cuatro la necrosis se vuelve difusa, hay evidencia de hipoxia en los hepatocitos centrilobulares. De manera similar, el bazo infectado con VPT es histológicamente normal hasta el día tres, cuando está presente la linfólisis, caracterizada por la fragmentación celular y la picnosis nuclear, dentro de las vainas periarteriolares. Degeneración celular y macrófagos que contienen hemosiderina y también se dispersaron restos celulares a lo largo del intersticio esplénico. Las lesiones esplénicas se localizan en la pulpa roja, la linfólisis se observa en la pulpa blanca. El duodeno puede evolucionar a una enteritis grave, se observa una leve necrosis que se considera un factor central que contribuye a la muerte. El hígado es el órgano principalmente afectado. Los pulmones llegan a manifestar una congestión vascular pulmonar marcada y hemorragia perivascular dispersa. También se observaron 
microhemorragias perivasculares multifocalmente en todo el cerebro. ${ }^{4,5}$

\section{PATOGÉNESIS}

La apoptosis inducida por VPT contribuye a la muerte de los hepatocitos y es responsable del daño hepático grave que se produce en ausencia de una infiltración celular inflamatoria secundaria. Los hepatocitos expresan «muerte» de los receptores en la superficie celular; esto quizás esté relacionado para facilitar la eliminación de las células infectadas con virus hepatotrópicos. En contraste, en la mitocondrial la ruta se desencadena por una variedad de estresores intracelulares, como daño en el ADN, privación del factor de crecimiento, perturbaciones del metabolismo y desprendimiento de la matriz y/o células circundante. VPT induce la apoptosis directamente en las células HepG2. EI TNF- $\alpha$ participa en la apoptosis inducida por VPT, posiblemente induciendo la activación de las proteasas de cisteína. ${ }^{6}$

\section{TRATAMIENTO}

De manera experimental se ha utilizado un agregado proteico de magnesio y amonio fosfolinoleatopalmitoleato anhídrido (P-MAPA, por sus siglas en ingles) administrada como una dosis única cada 24 horas. Ribavirina (50 mg/kg) dos veces al día durante cinco días. ${ }^{7}$

Otro compuesto experimental para el tratamiento es el IFN alfacon-1 (un interferón sintético de tipo I recombinante) en dosis de $5,1,0.5$ y $0.1 \mu \mathrm{g} / \mathrm{kg} / \mathrm{d} .{ }^{8}$

\section{CONCLUSIÓN}

El Virus de Punta Toro (VPT) fue aislado por primera vez de pacientes febriles en Panamá en 1966 y 1972. La prevalencia de anticuerpos neutralizantes contra VPT en un estudio en Panamá fue de $5 \%$ en niños menores de 20 años y de 27 a $40 \%$ en adultos. Dos cepas de VPT, Adames (VPT-A) y Balliet (VPT-B), difieren en su virulencia. VPT-A es altamente virulento, mientras que los aislamientos de VPT-B es más baja la virulencia. Las infecciones por VPT-A en hámsteres y ratones son muy similares a las infecciones por fiebre del Valle del Rift, causando daño tisular y necrosis hepática. ${ }^{5}$

Tanto en infecciones humanas como en animales los determinantes genéticos del hospedador probablemente contribuyen a la patogénesis del flebovirus. ${ }^{5}$

\section{REFERENCIAS}

1. Gundacker N, Carrera J, Castillo M, Díaz Y, Valenzuela J, Tamhane A et al. Clinical manifestations of Punta Toro virus species complex infections, Panama, 2009. Emerg Infect Dis. 2017; 23 (5): 872-874.

2. Palacios G, Wiley M, Travassos A, Guzman H, Quiroz E et al. Characterization of the Punta Toro species complex (genus Phlebovirus, family Bunyaviridae). J Gen Virol. 2015; 96: 2079-2085.

3. Stefan C, Chase K, Coyne S, Kulesh D, Minogue T et al. Development of real-time reverse transcriptase qPCR assays for the detection of Punta Toro virus and Pichinde virus. Virol J. 2016; 13: 54

4. Mendenhalla M, Wonga M, Skirpstunas R, Morreya J, Gowena B. Punta Toro Virus (Bunyaviridae, Phlebovirus) infection in mice: strain differences in pathogenesis and host interferon response. Virology. 2009; 395 (1): 143-151.

5. Ashleya S, Ameresa S, Gerrarda S, Foremand O, Eatona $\mathrm{K}$, etal. Host genetic variation in susceptibility to Punta Toro Virus. Virus Res. 2011; 157 (1): 71-75.

6. Xu F, Liang X, Tesh R, Xiao S. Characterization of cell-death pathways in Punta Toro virus-induced hepatocyte injury. J Gen Virol. 2008; 89: 2175-2181.

7. Durána N, Gowenc B, Costa F, Justoe G, Brocchi M, Nunes $O$ et al. A biotechnological product and its potential as a new immunomodulator for treatment of animal phlebovirus infection: Punta Toro virus. Antiviral Res. 2009; 83: 143-147.

8. Gowena B, Wonga M, Junga K, Blattb L, Sidwella R. Prophylactic and therapeutic intervention of Punta Toro virus (Phlebovirus, Bunyaviridae) infection in hamsters with interferon Alfacon-1. Antiviral Res. 2008; 77(3): 215-224.

Correspondencia:

Dr. Iván Renato Zúñiga Carrasco

E-mail: ivan.zuniga@imss.gob.mx 